\title{
Lifelong literacy: Towards a new agenda
}

\author{
Ulrike Hanemann ${ }^{1}$ - Veronica McKay ${ }^{2}$
}

Published online: 19 July 2015

(C) Springer Science+Business Media Dordrecht and UNESCO Institute for Lifelong Learning 2015

The Dakar Framework for Action (UNESCO 2000) aimed for basic education for all, including a massive improvement in levels of adult literacy by 2015. It provided a framework which strove to effect education as a fundamental human right, requiring countries to strengthen their efforts to ensure that the basic learning needs of every citizen were met. The six Education for All (EFA) goals agreed on at the Dakar World Education Forum in 2000 aimed to (1) expand and improve early childhood education; (2) ensure universal access to primary education; (3) ensure equitable access for all to appropriate learning programmes; it aimed to (4) improve the levels of adult literacy by 50 per cent; (5) eliminate gender disparities in primary and secondary education; and (6) improve the quality of education. These six goals were encapsulated in the second of the eight United Nations Millennium Development Goals (MDGs), which aimed at "achieving universal primary education" by 2015 (UN 2000); an aim which has not, in fact, been achieved. UNESCO's Director-General Irina Bokova states that "15 years of monitoring shows sobering results" (UNESCO 2015, Foreword). As the target year for the EFA goals and the MDGs draws to a close, reflections on the achievements and the lack of progress have fed into debates concerning the vision, shape and scope of the post2015 education agenda and how it might be integrated with the post-2015 sustainable development agenda.

Securing education and learning for sustainable futures is an issue which is high on this new agenda for 2016-2030. The discussions around the achievements - and the lack of progress - of the EFA goals are providing renewed impetus for

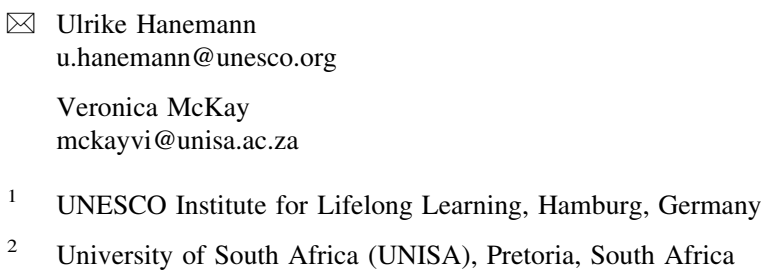


improving learning and literacy in both the developed and the developing world. The pressing need for a new and forward-looking education agenda to complete "unfinished business" and to extend efforts beyond the depth and scope of current goals has culminated in the proposed education-related targets of the Sustainable Development Goals (SDGs; UNESCO 2015), which are more closely aligned with an explicit lifelong learning framework than the EFA goals were (ibid.). This has impacted in particular on the target for youth and adult literacy. Hence, in expanding the vision of youth and adult literacy it is critical to better understand and operationalise it within a lifelong learning perspective. This necessity also underscores the significance of relevant research both for backing up informed decisions on literacy policies and strategies and for improving the quality of teaching and learning literacy and numeracy.

This special issue of the International Review of Education - Journal of Lifelong Learning (IRE) is entitled "Lifelong Literacy: Towards a New Agenda". The articles compiled here build on the deliberations of a high-level seminar held at the end of 2011 in Hamburg, Germany, at the UNESCO Institute for Lifelong Learning (UIL). The seminar aimed to develop a research outline for adult literacy and policy advice for the post-2015 agenda. Emerging from these discussions, the articles in this issue focus on current trends and critical issues in adult literacy.

Aiming to contribute to the development of a conceptual framework for literacy from a lifelong learning perspective, the articles provide theoretical and conceptual guidelines for the formulation of a forward-looking research agenda for literacy which will be serviceable until 2030, the SDG target year. The first three articles in this issue offer a conceptual basis for a post-2015 literacy agenda aimed at broadening the analysis of challenges in scope and depth, while the latter three articles contemplate possible applications of lessons learnt to the post-2015 literacy agenda, collating experiences of the way in which evidence-based approaches have helped to boost literacy.

\section{The scorecard}

The series of EFA Global Monitoring Reports which have been published by UNESCO since 2002 point to an increased awareness of the importance of learning on a global scale, but suggest slow and uneven progress towards these goals. The articles in this special issue focus on the global learning crisis emanating from poorquality education, low retention rates and weak learning outcomes, combined with poverty and gender discrimination.

While the number of out-of-school children and adolescents has fallen by almost half since 2000 (UNESCO 2015, p. 7), quantitative increases in the numbers of children accessing schooling have not been paralleled by qualitative outcomes, and the gains made in formal education and in youth and adult learning in general, and in literacy in particular, have been uneven across countries and within countries.

The failure to improve the quality of education and the resultant large proportions of children and adolescents who exit the schooling system without acquiring even the most basic literacy skills impacts on adult literacy across countries. The absence 
of a quality focus calls into question the global practice of setting quantitative goals or targets for literacy, a practice which has been unhelpful in improving proficiency levels in literacy.

The estimated 250 million children worldwide who are unable to master basic reading, writing and numeracy skills (UNESCO 2015, p. 18) attest to serious problems with the quality of teaching and learning in primary education. These children are destined to form part of the global pool of non- or low-literates, yet they are unlikely to gain access to meaningful learning opportunities later in life.

While much of the effort of literacy provision has focused particularly on literacy in the developing world, the existence of adult populations with poor literacy skills is not confined to countries in the Global South. Recent direct assessments of adult literacy skills in a number of economically more prosperous countries reveal a significant percentage of adults whose literacy and numeracy skills fall below a minimal proficiency level, highlighting the problem of low (or no) literacy skills in the developed world. It is estimated that 20 per cent of adults in Europe lack the literacy skills needed to fully participate in society (UIL 2010). Clearly, youth and adult literacy remain a key global challenge.

Worldwide, there are some 781 million youth and adults aged $15+$ who are reported to lack basic literacy skills (UNESCO 2015, p. 6). Of these, two-thirds are women. The benefits of literacy among women are well-documented and include their higher participation in the labour market, delayed marriage and improved child and family health and nutrition, the ability to transform their lives through increased participation in the public arena, and through the opening of opportunities to those who have been disenfranchised, marginalised and neglected.

While many countries have made efforts to improve literacy rates - the latest EFA Global Monitoring Report states that these have dropped from 18 to 14 per cent globally (UNESCO 2015, p. 135) - the increase in population growth has resulted in an increase in absolute numbers of youth and adults with low or no literacy skills in several countries, thus re-emphasising the need to increase the commitment to youth and adult literacy (Easton 2014, p. 5).

It was not therefore unexpected that the recommended post-2015 education goal (SDG 4; UNESCO 2015, p. 284) is to "ensure inclusive and equitable quality education and promote lifelong learning opportunities for all", with the sixth (4.6; ibid., p. 285) among its eight targets prioritising youth and adult literacy. This target is intended to ensure that, globally, all youth (aged between 15 and 24 years) and adults achieve relevant and recognised literacy and numeracy proficiency levels which are equivalent to the levels of competence at the end of primary school and enable access to lifelong and life-wide learning opportunities.

The weak connections among literacy activities across sectors, generations and spheres of life have been identified as a major hurdle to the promotion of literacy from a lifelong learning perspective. The recognition of the importance of literacy as a "dynamic nexus of social relations" and the critical web of social relations which, through language, enables individuals and communities to interact over time and across space, is a first step towards a more integrated approach to literacy. Sustaining literacy relies on such approaches for building partnerships among stakeholders and literate environments with an expanded vision. 


\section{The articles}

Our first article, entitled "Literacy in the 21st century: Towards a dynamic nexus of social relations", is by Aaron Benavot and sets the backdrop for this special issue. Conceiving literacy as a social nexus entails developing strong links between existing national development policies and community priorities; establishing ties between different governmental ministries; and enabling civil society organisations, NGOs and faith-based associations to foster strong stakeholder partnerships in support of literacy-enhancing activities. These interdependencies also relate to literacy throughout the life course - from childhood through to old age, as intergenerational approaches between (grand-)parents and children; and connecting different spheres of an individual's life, including the public and the private; the economic and the cultural, and in a social nexus of relations among individuals, households, communities and social institutions. Benavot argues that literacy thrives and is sustained when a state of connectedness exists: when there is a social nexus of relations among individuals, households, communities and social institutions. He thus makes a case for policies which are more "connected", stating that this connected dimension is necessary if literacy is to be shifted from its perpetual status of being the "forgotten goal".

Our second article, by Guest Editor Ulrike Hanemann, is entitled "Lifelong literacy: Some trends and issues in conceptualising and operationalising literacy from a lifelong learning perspective". It addresses the need for literacy to be conceptualised as a foundation for lifelong learning. She argues that lifelong learning is becoming increasingly important, not only as a key organising principle for all education, but also as a necessity for everyone. In the context of a fastchanging and highly inequitable world, it is essential in particular for the disadvantaged or those who did not acquire basic competencies through formal schooling. She points out that, within a lifelong learning framework, literacy and numeracy are foundational skills which are indispensable to full participation in society. Hanemann elaborates on some of the current trends in literacy, the most important being that literacy is perceived as a learning continuum of different proficiency levels. She examines findings of the national reports submitted for the Second Global Report on Adult Learning and Education (UIL 2013), a desk study of national literacy campaigns and programmes, as well as some recent developments in the area of formal education against an analytical framework of literacy as a lifelong and life-wide learning process and as part of lifelong learning systems. Based on this research, Hanemann offers conclusions for both the policy and the practice of literacy, as a foundation of lifelong learning, and shows how they might contribute to the ongoing post-2015 education debate, specifically with regard to mainstreaming youth and adult literacy in the implementation of the sustainable development agenda.

The discussions on the future of the United Nations MDGs give rise to a number of research questions on how to improve literacy rates, and the general educational quality in poor communities in low-income countries in the post-2015 period, with language issues being central. Daniel Wagner refers to these issues in his article 
entitled "Learning and literacy: A research agenda for post-2015". He draws attention to the highly complex nature of literacy and learning and argues that the factors which influence learning and literacy development are multifaceted and intertwined. This complexity, he contends, is one of the reasons why universal literacy has still not been achieved in spite of major investments over the years. Wagner also refers to the often unrecognised mutually reinforcing and reciprocal perspectives for child and adult literacy, pointing out that adult literacy acquisition has a lot in common with children's literacy acquisition, which is supported by wellresearched body of knowledge on reading acquisition. Moreover, Wagner is critical of the global practice of setting quantitative goals or targets for literacy. Rather than treating literacy attainment as a statistical exercise, he argues for a common understanding of what "can read" means in instrumental and measurable terms; and how one would reach such a goal in terms of the knowledge resources required. Addressing the challenges the post-2015 agenda is facing will require robust research, leading Wagner to conclude by proposing ten major areas of learning and literacy research priorities.

While the actual extent of literacy is usually examined in terms of the achievement of the developmental goals, the article written by Malini Ghose and Disha Mullick, entitled "A tangled weave: Tracing outcomes of education in rural women's lives in North India" looks beyond these goals and explores issues and challenges in literacy from a gender perspective. Their article focuses on the link between literacy and women's empowerment and identifies key challenges in achieving gender equality through effective literacy policies and programmes. Their paper seeks to analyse women's perceptions on how becoming literate and participating in an empowering education programme subsequently helped shape the trajectories of their lives. The paper, based on a longitudinal study conducted in Northern India, traces the long-term impact of educational programmes on adult women some 15 years after they participated in a women's education and empowerment programme. Ghose and Mullick demonstrate the nuanced transformative effects of such programmes through the narratives of the women, which they contrast with the prevalent discourses around women's literacy and empowerment that usually highlight the importance of literacy only in terms of its positive effect on attaining development goals. Crucially, they show that when informed by a critical feminist understanding, empowerment through education is embedded in women's everyday lives and enables women to find spaces in their personal and public lives to exercise agency.

The need for adult education programmes to ensure standardised learner assessment methods, using effective tools for measuring learning outcomes and for monitoring and ensuring accountability, has been identified as a way to improve planning and monitoring towards improved quality of provision. Guest Editor Veronica McKay's article, entitled "Measuring and monitoring in the South African Kha Ri Gude mass literacy campaign", discusses the need to develop a practical form of assessment to assess the learning outcomes of learners in the context of the award-winning South African Literacy Campaign. Her article focuses on the development and use of a structured and standardised Learner Assessment Portfolio (LAP), which serves as both a formative and diagnostic tool through which learners' 
growing competences are continuously assessed. McKay describes how, after overcoming the challenges of a participative mode of assessment, the portfolio added a valuable dimension to the monitoring of the campaign. She traces how, within the South African National Qualifications Framework, a well-orchestrated national and large-scale system has been set up to implement a standardised portfolio learner assessment approach, which is moderated and verified by the national qualifications authority. McKay argues that the model for assessment and monitoring, coupled with high-quality learner materials, enables the large-scale South African Literacy Campaign to mitigate the challenges of learning which are closely associated with large-scale adult literacy programmes, enabling learners to become competent as a prerequisite for empowerment.

Another aspect of ensuring effective policies for literacy is the need to create a literate environment for sustaining literacy. An enriched literate environment affects the way in which literacy skills are acquired, practised and retained. Creating such an environment entails, inter alia, enhancing the availability of written, printed and visual materials in learners' surroundings so as to encourage their use of their basic reading and writing skills. Concluding this special issue, Sanjana Shrestha and Lisa Krolak present an example for sustaining and developing literacy skills through community-based libraries in Nepal in their article entitled "The potential of community libraries in supporting literate environments and sustaining literacy skills". Following Peter Easton (2009), they argue that a literate environment is much more than merely the availability of reading and writing materials. While ensuring that the supply side of literacy provision is attended to, attention also needs to be given to the demand side of literacy to encourage and promote the practical uses of literacy. The crucial role of librarians as facilitators comes under the spotlight as the authors argue that their mission goes beyond merely dispensing books. They need to be attuned to reaching out and playing a role in building communities by partnering stakeholders such as community leaders, municipal and district officials, school principals and teachers and parents. Based on experiences and impact evaluations from Nepal's Rural Education and Development (READ) Centres, which have evolved from traditional libraries to effective community development centres, Shrestha and Krolak draw conclusions with regard to a library concept which is needs-based, community-owned and sustainable in order to tap the full potential of community libraries for the development of literate environments.

\section{Concluding remarks}

While the 2015 reviews of the MDGs and EFA have reasserted the importance of adult learning and ensure that it is firmly placed on the post-2015 agenda, the debates around the achievement and lack of achievement of the MDGs has given a new impetus for the repositioning of literacy in a lifelong and life-wide perspective.

The renewed emphasis on adult education within a framework of lifelong learning underscores literacy as a necessary component of the right to education, and as a public good. It accentuates literacy as an indispensable foundation for independent learning (UIL 2010) and essential for accessing opportunities for 
lifelong learning. The six contributions in this special issue entitled "Lifelong Literacy: Towards a New Agenda" aim to highlight the challenges education is facing subsequent to the MDG benchmark year 2015. They make theoretical and conceptual contributions and share successful experiences from India, South Africa and Nepal, which could enhance the formulation of a post-2015 literacy agenda for sustainable development.

This new agenda will require that policy and programmes are supported by research and related action on how to redefine and redesign learning as a democratic entitlement, in a way that no one is left behind. We believe that this special issue goes some way towards enriching this critical debate.

\section{References}

Easton, P. B. (2009). Creating a literate environment: Hidden dimensions and implications for policy. In ADEA (Ed.), More and better education: What makes effective learning in African literacy programs? Lessons learned. Tunis: Association for the Development of Education in Africa. Accessed 3 January 2014 from http://www.sciencedirect.com/science/article/pii/S0738059313000345/pdfft?md5=115fe3e8c1f3 633e9e6cec38bc629c8e\&pid=1-s2.0-S0738059313000345-main.pdf.

Easton, P. (2014). Sustaining literacy in Africa: Developing a literate environment. Paris: UNESCO. Accessed 1 July 2014 from http://unesdoc.unesco.org/images/0022/002252/225258e.pdf.

UIL (UNESCO Institute for Lifelong Learning) (2010). CONFINTEA VI: Belém framework for action: Harnessing the power and potential of adult learning and education for a viable future. Hamburg: UIL. Accessed 3 January 2014 from http://unesdoc.unesco.org/images/0018/001877/187789m.pdf.

UIL (2013). Second global report on adult learning and education: Rethinking literacy. Hamburg: UIL. Accessed 3 January 2014 from http://unesdoc.unesco.org/images/0022/002224/222407E.pdf.

UN (United Nations) (2000). United Nations Millennium Declaration. New York: United Nations. Accessed 31 May 2015 from http://www.un.org/millennium/declaration/ares552e.htm.

UNESCO (2000). The Dakar framework for action. Education for all: Meeting our collective commitments. Paris: UNESCO. Accessed 31 May 2015 from http://unesdoc.unesco.org/images/ 0012/001211/121147e.pdf.

UNESCO (2015). Education for all 2000-2015: Achievements and challenges. EFA Global Monitoring Report 2015. Paris: UNESCO. Accessed 31 May 2015 from http://unesdoc.unesco.org/images/0023/ 002322/232205e.pdf.

\section{The authors}

Ulrike Hanemann is a senior programme specialist at the UNESCO Institute for Lifelong Learning (UIL), focusing on research, capacity development and networking in the field of literacy, non-formal education and adult learning from a perspective of lifelong learning. She coordinates UIL's literacy and basic skills programme and has developed and/or contributed to several research, evaluation and capacity development projects in the field of literacy in different countries around the world. Before joining UNESCO in 2001, she worked for ten years as a lecturer and advisor at the National Autonomous University of Nicaragua in pre-service teacher formation and postgraduate programmes for university staff.

Veronica McKay is the Deputy Executive Dean in the College of Education, University of South Africa (UNISA), where she is responsible for the implementation of programmes for initial and continuous development of teachers, from preschool to post-schooling, including adult and community education and training. Her research areas include non-formal education and adult learning and literacy, secondlanguage teaching, gender and development issues. She was previously seconded from the university to 
the South African Department of Basic Education where she was appointed Chief Executive Officer of the South African Literacy Campaign, and prior to this, she led the UNISA component of the South African Literacy Initiative. 